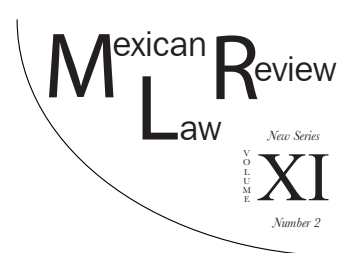

\title{
SHOULD MEXICO ADOPT PERMISSIVE GUN POLICIES: LESSONS FROM THE UNITED STATES
}

\author{
Eugenio Weigend VARGas* \\ David PÉREZ EsPARZA**
}

\begin{abstract}
After a recent increase in violence, policy makers and advocates in Mexico have proposed new firearm legislation that would shift Mexican gun policies towards a more permissive approach. Following the argument of 'selfdefense', these initiatives would facilitate citizens' access to guns by allowing them to carry firearms in automobiles and businesses. These initiatives have been developed without a deep analysis of the effects of permissive gun laws. In this article, the authors present an assessment of what Mexican policymakers and advocates should be aware of regarding permissive gun laws using the example of the United States, the nation with the highest rate of gun ownership in the world and where these policies are already in effect.
\end{abstract}

Keywords: Permissive Gun Laws, Self-Defense, National Rifle Association, Second Amendment, Gun Violence.

Resumen: Ante el reciente incremento de violencia en México, algunos tomadores de decisión y grupos ciudadanos han comenzado a debatir propuestas legislativas que modificarían la política de armas en México hacia un enfoque más permisivo. Bajo el argumento de 'legítima defensa', estas iniciativas, por ejemplo, facilitarían el acceso a armas de fuego a los ciudadanos al permitírseles portar armas en automóviles y negocios. Estas iniciativas se han presentado sin un análisis profundo sobre los efectos de regulaciones permisivas en otros países. En este ensayo, los autores presentan una evaluación sobre lo que los tomadores de decisiones en México deben de considerar sobre regulaciones permisivas en Estados Unidos, un país donde ya se implementan regulaciones similares y la nación con más armas de fuego per cápita en el mundo.

* Ph.D From Tecnologico de Monterrey and Master's degree from Brown University. Email:eugeniowr@gmail.com.

** Master in Public Policy, a Master in Political Economy \& Conflict Resolution, and a Master in Security and Crime Science. He currently completes a PhD in University College London (UCL). Email: d.perez.esparza.13@ucl.ac.uk. 
Esta revista forma parte del acervo de la Biblioteca Jurídica Virtual del Instituto de Investigaciones Jurídicas de la UNAM http://www.juridicas.unam.mx/ https://biblio.juridicas.unam.mx/bjv https://revistas.juridicas.unam.mx/ http://dx.doi.org/10.22201/iij.24485306e.2019.1.13127

Palabras clave: Regulaciones permisivas, Defensa Propia, Asociación $\mathrm{Na}$ cional del Rifle, Segunda Enmienda, Violencia asociada a las armas de fuego.

\section{TABle of Contents}

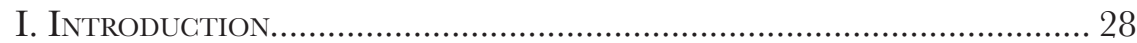

II. Mexican Gun Laws and New Proposals ......................................... 30

III. Actors and Gun Policies In the United States................................. 34

IV. Impacts of Permissive Gun Laws in the U.S....................................... 40

V. Policy Implications and Gonclusions ............................................... 50

\section{INTRODUCTION}

Regardless of efforts and resources invested by federal and local institutions, crime continues to be one of the biggest challenges in Mexico. 2017 was the year with the highest rate of homicides in the past 20 years. ${ }^{1}$ A similar situation is reported with regard to other crimes. From 2007 to 2017, kidnappings and extortions increased dramatically, rising 162 and 81 percent respectively. ${ }^{2}$

Evidence suggests that, aside from other contributing factors, an expansion of the illegal firearms market in Mexico has played a major role in fueling violence. Some studies have linked the increase of illegal firearms in México to the expiration of the Assault Weapons Ban (AWB) in the U.S. in 2004. This ban triggered opportunities for gun traffickers along the U.S.-Mexico border and contributed to an escalation of violence in Mexico. ${ }^{3}$

Gun violence has become a serious issue in Mexico. According to the 2017 National Victimization Survey (ENVIPE), one third of the 17 million crimes that occurred in 2016 in which a victim was present involved the use of a firearm. ${ }^{4}$ This phenomenon has a major impact considering that 34 percent of the households in Mexico included at least one victim of crime in $2016 .^{5}$

1 José Roberto Cisneros, 2017 Tiene el Arranque de Año más Violento en dos Décadas, Expansion May 2, (2017), available at http://expansion.mx/nacional/2017/05/02/2017-tiene-el-arranque-deano-mas-violento-en-al-menos-dos-decadas.

2 Analysis of Secretario Ejecutivo del Sistema Nacional de Seguridad Pública (SNSP), Delitos del Fuero Común 2017 (2017); Secretario EJecutivo del Sistema Nacional de Seguridad Pública (SNSP), Delitos del Fuero Común 2007 (2007).

3 David Pérez Esparza \& Eugenio Weigend, Más armas, más homicidios, Revista Nexos September 1, (2013), available at http://wrere.nexos.com.mx/?p=15496; Arindrajit Dube, Oeindrila Dube and Omar Garcia Ponce, Cross-Border Spillover: US Gun Laws and Violence in Mexico, 107 American Political Science Association 3, 397-417 (2013).

4 Instituto Nacional de Estadística y Geografía (INEGI), Encuesta Nacional de Victimización y Percepción sobre Seguridad Pública 2017 (2017).

5 Id. 
Esta revista forma parte del acervo de la Biblioteca Jurídica Virtual del Instituto de Investigaciones Jurídicas de la UNAM http://www.juridicas.unam.mx/ https://biblio.juridicas.unam.mx/bjv https://revistas.juridicas.unam.mx/

Crimes committed with guns have increased markedly over time. While firearms were used in 58 percent of violent crimes committed with some type of weapon in 2005, this figure increased to 68 percent by $2015 .{ }^{6} \mathrm{~A}$ similar pattern is reported for homicides. Thirty nine percent of all murders were committed with a gun in 2007, compared to 67 percent in 2017, an all-time high. $^{7}$

The increase in gun related violence has triggered discussions of unconventional measures aiming to reduce and tackle violence in Mexico. A small group of Mexican politicians as well as gun-advocates have proposed changing existing gun regulations and adopting a more permissive approach. This approach would allow citizens to carry guns outside of their residence. ${ }^{8} \mathrm{It}$ would allow citizens to easily acquire firearms for self-defense through the opening of gun shops outside Mexico City. ${ }^{9}$ In addition, recent state level initiatives that are not directly associated with firearm policies have contributed to more permissive gun approaches. In 2016, a congressman from the state of Nuevo Leon introduced legislation to extend the definition of self-defense within a household. ${ }^{10}$ This initiative was passed in March 2017.

As policy makers and advocates in Mexico advocate for a more permissive approach to gun laws, it is essential to analyze and understand international experiences. In this regard, the United States is a relevant case study for two reasons. The U.S. is the country with the highest rate of gun ownership in the world, and the proposed legislation in Mexico would replicate many of the laws already in force in the United States.

Assessing the impacts of permissive gun laws in the United States involves looking not only at their effects on violence but also their impact on key out-

6 Instituto Ciudadano de Estudios sobre la Inseguridad (ICESI), Tercera Encuesta NaCiOnal SObRe Inseguridad 2005 (2005); Instituto Nacional de Estadística y Geografía (INEGI), Encuesta Nacional de Victimización y Percepción sobre Seguridad Pública 2016 (2016).

7 Secretario Ejecutivo del Sistema Nacional de Seguridad Pública (SNSP), Delitos del Fuero Común 2017 (2017); Secretario Ejecutivo del Sistema Nacional de Seguridad Pública (SNSP), Delitos del Fuero Común 2007 (2007).

8 Mexican Senate (2016), Iniciativa con Proyecto de Decreto con el que se reforma el artículo 10 de la Constitución, Proposal by Senator Jorge Luis Preciado, presented 08/11/2016, in discussion up to November 2017, available at http://rewere.senado.gob.mx/sgsp/ gaceta/63/2/2016-10-11-1/assets/documentos/Inic_PAN_art-10_Const_Armas.pdf.

9 Nuevo León State Congress (2016), Exhorto a la Secretaria de Defensa Nacional SEDENA para que abra una segunda armería en el Estado de Nuevo León. Proposal by State Congressman Ángel Barroso, presented 29/05/2017, in discussion up to November 2017, available at http://wrere.hcnl.gob.mx/trabajo_legislativo/pdf/DD\%20SO\%20-\%20202\%20 MEL\%20OK.doc.

10 Nuevo León State Congress (2016), Iniciativa con Proyecto de Decreto con el que se modifica el artículo 17 del Código Penal del Estado de Nuevo León. Proposal by State Congressman Marcos Mendoza Vazquez, presented 08/11/2016 and approved 29/05/2017, available at http://wrere.hcnl.gob.mx/trabajo_legislativo/iniciativas/pdf/LXXIV-2016-EXP10390DIP. MARCOS\%20MEDONZA\%20VQZ\%20INICIATIVA\%20DE\%20PROIECTO\%20DEC\%20 ART\%2017\%20CODIGO\%20PENAL.pdf. 
comes such as gun theft and illegal arms trafficking. This article addresses key questions about the U.S.'s permissive approach towards gun laws, in an effort to contribute to an informed debate, and to understanding the differences between the U.S. and México in this regard. What are the outcomes of gun laws in the U.S.? Do these laws reduce violence and crime? What are other impacts of permissive gun laws? How does the U.S. fare in comparison to other developed nations? Within the U.S., are there differences amongst the 50 states?

This article is divided into five sections. After introducing the problem and the key objectives, we discuss Mexico's gun laws and the new proposals in section two. In section three, we address laws and actors involved in crafting and passing gun policies in the U.S., examining the Second Amendment of the U.S. Constitution and the National Rifle Association (NRA), a key player pushing for the implementation of increasingly permissive gun laws. Section four analyzes existing literature addressing gun violence in the U.S. Finally, in section five, we outline our main conclusions and offer a series of policy recommendations.

\section{Mexican Gun Laws and New Proposals}

Article 10 of the Mexican constitution states that, so long as the objective is of self-defense and protection, citizens have the right to possess a firearm in their residence. This article specifies that the Federal Firearms and Explosives Law (Ley Federal de Armas de Fuego y Explosivos, LFAFE) will determine the conditions, cases and requirements authorizing gun possession. ${ }^{11}$

All firearm regulations are enacted and decided at a federal level. Firearm purchases must be registered in the Federal Firearms Registry (Registro Federal de Armas), which is administered by the National Defense Ministry (Secretaría de la Defensa Nacional, SEDENA). ${ }^{12}$ At the time of publication of this article there are 46 modules in the country where citizens can register their firearms.

In Mexico several firearms and calibers of weapons are reserved for exclusive use by the military. ${ }^{13}$ These include calibers for the AR-15 and AK47 semi-automatic rifles, weapons commonly used and illegally acquired by criminal groups in Mexico. ${ }^{14}$ Mexico's federal government, through SED-

11 Constitución Política de los Estados Unidos Mexicanos [Const.], as amended, Diario Oficial de la Federación [D.O.], 5 de febrero de 1917 (Mex.).

12 Ley Federal de Armas de Fuego y Explosivos [L.F.A.F.E.] [Federal Law of Firearms and Explosives] as amended, Article 2 and 7, Diario Oficial de la Federal [D.O.] 23 de enero, 2004 (Mex).

13 Ley Federal de Armas de Fuego y Explosivos [L.F.A.F.E.] [Federal Law of Firearms and Explosives] as amended, Article 11, Diario Oficial de la Federal [D.O.] 23 de enero, 2004 (Mex).

14 Colby Goodman \& Michel Marizco, U.S. Firearms Trafficking to Mexico: New Data and Insights Illuminate Key Trends and Challenges, The WiLson Center 187 (2010), available at 
ENA, has the faculty to authorize the opening of firearm factories and establishments. SEDENA is responsible for administering and supervising industrial operations involving firearms, ammunition as well as restricted chemical substances. ${ }^{15}$ SEDENA only operates one gun shop in Mexico. ${ }^{16}$

Mexico's National Defense Ministry also regulates conditions for gun possession by citizens within their place of residence. Article 15 of LFAFE states that citizens can possess firearms within their residence, ${ }^{17}$ however, all firearms must be registered with SEDENA and in accordance to Article 16, citizens may only register a single residence. ${ }^{18}$

On the whole, Mexico's gun laws are strict in comparison to other countries. ${ }^{19}$ However, given an increase in violence in Mexico, policy makers have proposed legislation that would shift Mexico's gun laws to a more permissive approach. For instance, at the end of 2016, a Senator from the conservative National Action Party (PAN) proposed an initiative that would extend legal, individual firearm possession to business and vehicles. ${ }^{20}$ Senator Jorge Luis Preciado Rodriguez proposed a modification to Articles 15 and 16 of LFAFE to legalize the possession of a firearm in businesses and private vehicles ${ }^{21}$ and to allow citizens to register a business address as well as vehicle information in addition to a single residence. ${ }^{22}$ In other words, citizens would be allowed to register their business as well as their vehicle as places where they could legally carry their firearms.

https://weww.wilsoncenter.org/sites/default/files/Chapter\%206-\%20U.S.\%20Firearms\%20Trafficking\%20 to $\% 20$ Mexico, $\% 20$ New $\% 20$ Data $\% 20$ and $\% 2$ Insights $\% 20$ Illuminate $\% 20$ Key $\% 20$ Trends $\% 20$ and $\%$ 20Challenges.pdf.

15 Ley Federal de Armas de Fuego y Explosivos [L.F.A.F.E.] [Federal Law of Firearms and Explosives] as amended, Article 37, Diario Oficial de la Federal [D.O.] 23 de enero, 2004 (Mex).

16 Esta es la única tienda en México para comprar armas legalmente, ExcÉLSIOR, (Aug. 17, 2016), available at http://wrerce.excelsior.com.mx/nacional/2016/08/17/1111571.

17 Ley Federal de Armas de Fuego y Explosivos [L.F.A.F.E.] [Federal Law of Firearms and Explosives] as amended, Article 15, Diario Oficial de la Federal [D.O.] 23 de enero, 2004 (Mex).

18 Ley Federal de Armas de Fuego y Explosivos [L.F.A.F.E.] [Federal Law of Firearms and Explosives] as amended, Article 16, Diario Oficial de la Federal [D.O.] 23 de enero, 2004 (Mex).

19 United Nations Office on Drugs and Crime (UnODG), Transvational Organized Crime Threat Assessment: Firearms (section 6.1), available at https://wrere.unodcorg/documents/ data-and-analysis/tocta/6. Firearms.pdf.

20 Susana Guzmán, Senador del PAN propone la portación de armas para legitima defensa, EL FINANCIERO, October, 6, 2016, available at http://wrerrelffinanciero.com.mx/nacional/senador-del-panpropone-la-portacion-de-armas-para-legitima-defensa.html; Mexican Senate (2016), Iniciativa con Proyecto de Decreto con el que se reforma el artículo 10 de la Constitución. Proposal by Senator Jorge Luis Preciado, presented 08/11/2016, in discussion up to November 2017, available at http://wrerresenado.gob.mx/sgsp/gaceta/63/2/2016-10-11-1/assets/documentos/ Inic_PAN_art-10_Const_Armas.pdf.
21 Id.
22 Id. 
Esta revista forma parte del acervo de la Biblioteca Jurídica Virtual del Instituto de Investigaciones Jurídicas de la UNAM http://www.juridicas.unam.mx/ https://biblio.juridicas.unam.mx/bjv https://revistas.juridicas.unam.mx/ http://dx.doi.org/10.22201/iij.24485306e.2019.1.13127

This proposal gained some momentum towards the end of 2016. In fact, during a Senate hearing in November 2016, organizations from the civil society as well as advocates and academics participated in a debate to address this proposal. ${ }^{23}$ Pro-gun advocates presented arguments in favor of this proposal, and non-governmental organizations presented arguments against it. More recently, a 2017 survey suggests that the overall population in Mexico believe that violence would increase with these types of policies. ${ }^{24}$ In this regard, as of June 2018, efforts to modify Articles 15 and 16 of LFAFE have been unsuccessful and the proposal has not been approved.

In early 2017, a local Congressman from the state of Nuevo León proposed the opening of a second gun shop in the country in the northern city of Monterrey. ${ }^{25}$ As stipulated in Article 37 of LFAFE, Mexico's gun laws are decided at a Federal level and hence, authorization from the President is needed to open an additional establishment. The Congressman's proposal was, in effect, to request that federal authorities open a second gun shop in the country. For this to happen, this proposal would require executive action, not legislative discussion. As of November 2017, this proposal has not been approved.

Finally, while some legislative initiatives are not directly related to gun laws, they complement and facilitate the adoption of more permissive gun laws. A congressman from the state of Nuevo Leon introduced legislation that would extend the definition of self-defense within a residence. This amendment would legally shelter citizens who injure or kill someone within their residence, and protects a person who kills an intruder before entering a residence. The state of Nuevo Leon approved this initiative in March 2017. ${ }^{26}$

23 Mexican Senate, Version Estenografica del foro de análisis sobre la iniciativa de reforma a la Ley Federal de Armas de Fuego y Explosivos (Primera parte) (2016), available at http://comunicacion.senado.gob.mx/index.php/informacion/versiones/32538-version-estenografica-del-foro-de-analisis-sobre-la-iniciativa-de-reforma-a-la-ley-federal-de-armas-de-fuego-y-explosivosprimera-parte.html; Mexican Senate, Version Estenografica del foro de análisis sobre la iniciativa de reforma a la Ley Federal de Armas de Fuego y Explosivos (Segunda parte y FINAL) (2016), available at http://comunicacion.senado.gob.mx/index.php/informacion/versiones/32564version-estenografica-del-foro-de-analisis-sobre-la-iniciativa-de-reforma-a-la-ley-federal-de-armas-de-fuego-yexplosivos-segunda-parte-y-final.html.

24 David Perez Esparza \& David Hemenway, What is The Level of Household gun own-

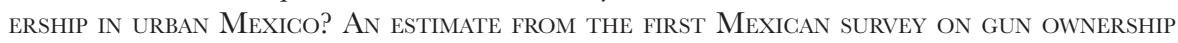
2017, InJury Prevention (2018).

25 Ricardo Alanís, Propone Barroso instalar tienda de armas en NL, Milenio Noticias, (Apr. 30, 2017), available at http://wrere.milenio.com/region/tienda_armas-barroso-sedena-milenio-noticias-monterrey_0_965903594.html; Nuevo León State Congress (2016), Exhorto a la Secretaria de Defensa Nacional SEDENA para que abra una segunda armería en el Estado de Nuevo LEÓn, proposal by State Congressman Ángel Barroso, presented 29/05/2017, in discussion up to November 2017. Available at: http://wrere.hcnl.gob.mx/trabajo_legislativo/pdf/DD\%20SO\%20-\%20 202\%20MEL\%20OK.doc.

26 Nuevo León State Congress, Dictamen 10390 y anexo pOR EL Que se amplía la LEGÍtima DEFENSA, proposal 10390/LXXIV, presented 08/11/2016 by State Congressman 
Esta revista forma parte del acervo de la Biblioteca Jurídica Virtual del Instituto de Investigaciones Jurídicas de la UNAM http://www.juridicas.unam.mx/ https://biblio.juridicas.unam.mx/bjv https://revistas.juridicas.unam.mx/

These legislative proposals at the national and local level are relevant from a historical and a policy perspective. For instance, they would structurally modify the Mexican gun policy which is widely considered to be one of the most restrictive in the world. ${ }^{27}$ Perhaps more importantly they would increase the accessibility of firearms among civilians. For instance, the proposal to open a gun shop in Monterrey may create pressure to establish more gun shops elsewhere. In turn, this could lead to further incentives to remove existing restrictions on high caliber firearms as well as eroding the army's capabilities for enforcing the background checks that are carried out before every gun sale. Overall, these proposals would likely shift Mexico's gun policies towards a more permissive approach.

Irrespective of the possible impacts of these proposals, pro-gun advocates have insisted that given the incapacity of Mexican institutions to guarantee security, firearms in the hands of civilians would protect them from criminals. ${ }^{28}$ Interest groups and policy makers that push for a more permissive approach in Mexico often cite U.S. gun laws as a model to analyze and replicate. In fact, the Senator proposing changes to Articles 15 and 16 of LFAFE admitted that he based his proposal on the United States' Second Amendment. ${ }^{29}$

U.S. gun policies are considered more permissive than Mexico's. In the U.S., many gun laws are determined at a state level and in contrast to Mexico, every state allows for some form of concealed carrying of guns by citizens outside of their residence. In fact, 12 states allow a person to carry a concealed firearm in public without the need of a permit. ${ }^{30}$ In other states, guns are allowed in vehicles, churches, bars, universities and schools. ${ }^{31}$

Marcos Mendoza Vázquez, approved by Congress 29/05/2017, available at http://wrerre.hcnl.gob. mx/trabajo_legislativo/pdf/DICTAMEN-10390\%20y\%20anexo.docx.

27 United Nations Office on Drugs and Crime (UnODG). Transvational Organized Crime Threat Assessment: FiRearms (SECTION 6.1), available at https://wrerceunodcorg/documents/ data-and-analysis/tocta/6. Firearms.pdf.

28 Senado de la Republica, Versión Estenográfica del foro de análisis sobre la inIciativa de reforma a la Ley Federal de Armas de Fuego y Explosivos, Primera Parte (2016), available at http://comunicacion.senado.gob.mx/index.php/informacion/versiones/32538-versionestenografica-del-foro-de-analisis-sobre-la-iniciativa-de-reforma-a-la-ley-federal-de-armas-de-fuego-y-explosivos-primera-parte.html; SENAdO de la Republica, Versión EstenOGRáfica dEL FORO DE ANÁLISIS sobre la iniciativa de reforma a la Ley Federal de Armas de Fuego y Explosivos, Segunda PARTE (2016), available at http://comunicacion.senado.gob.mx/index.php/informacion/versiones/32564version-estenografica-del-foro-de-analisis-sobre-la-iniciativa-de-reforma-a-la-ley-federal-de-armas-de-fuego-yexplosivos-segunda-parte-y-final.html.

29 Id; Héctor Figueroa Alcántara, Proponen armar a la población; el estado fracaso: Preciado, ExCÉLSIOR, (Oct. 7, 2016), available at http://wrerreexcelsior.com.mx/nacional/2016/10/07/1120970.

30 Giffords Law Center, Concealed CARry, available at http://lawcentergiffords.org/gunlawes/policy-areas/guns-in-public/concealed-carry/\#federal.

31 See for example the different state laws addressing guns in Schools, GifFords Law CENTER, GUNS IN SCHOOLS, available at http://laweentergiffords.org/gun-lawes/policy-areas/guns-in-public/ guns-in-schools/. 
Esta revista forma parte del acervo de la Biblioteca Jurídica Virtual del Instituto de Investigaciones Jurídicas de la UNAM http://www.juridicas.unam.mx/ https://biblio.juridicas.unam.mx/bjv https://revistas.juridicas.unam.mx/ http://dx.doi.org/10.22201/iij.24485306e.2019.1.13127

In addition, the United States has thousands of gun shops. According to information from the Bureau of Alcohol, Tobacco, Firearms and Explosives, there were close to 56,000 firearm dealers by the end of $2017 .{ }^{32}$ Additionally, individuals can purchase firearms on the Internet or through numerous gun shows that take place each year. ${ }^{33}$

We must ask, however, if US gun laws can be considered a success in reducing violence or deterring crime? If policy makers and gun advocates in Mexico are pushing for a more permissive approach towards gun laws and are using the United States as a model, it is fundamental to conduct an analysis of U.S. gun laws and their effects. The following sections of this article analyze the context of permissive gun laws in the United States as well as their effects on violence and other outcomes.

\section{Actors and Gun Policies in the United States}

A key element for understanding gun policy in the U.S. is the Second Amendment. Written more than two hundred years ago, this amendment to the U.S. Constitution reads as follows "A well-regulated Militia, being necessary to the security of a free State, the right of the people to keep and bear Arms, shall not be infringed." This is the backbone upon which all firearm regulations in the U.S. are based.

There have been several interpretations and debates surrounding the Second Amendment. On the one hand, there are those who suggest that the it exclusively provides the right to possess guns to members of the military, and that by contrast, it does not protect individual gun ownership. ${ }^{34}$ In fact, following this argument, in Salina v. Blaksley the Kansas Supreme Court agreed that the purpose of the Second Amendment was to guarantee the continuation as well as effectiveness of the state militia. ${ }^{35}$

However, a recent decision by the U.S. Supreme Court (District of Columbia vs. Heller) written by Justice Antonin Scalia held that the Second Amend-

32 Bureau of Alcohol, Tobacco, Firearms and Explosives (ATF), Listing of Federal Firearms Licensees (FFLs) -2017, available at https://wwre.atf.gov/firearms/listing-federal-firearms-licenseesffs-2017. These dealers do not include collectors, Pawnbrokers, manufactures of destructive devices or importers. This information is current as of December 2017.

33 Garen Wintemute, Inside Gun Shows, University of California David School of MediCINE, available at https://wrerw.ucdmc.ucdavis.edu/vprp/pdf/IGS/IGScoverprefweb.pdf.

34 John Paul Stevens, The five extra words that can fix the Second Amendment, THE New York TIMEs, (Apr. 4, 2014), available at https://wrww.washingtonpost.com/opinions/the-five-extra-wordsthat-can-fix-the-second-amendment/2014/04/11/f8a19578-b8fa-11e3-96ae-f2c36d2b1245_story. html:utm_term $=. c 434922 e a b 81$.

35 Giffords Law Center, State Right to Bear Arms in Kansas, available at http://smartgunlaws.org/state-right-to-bear-arms-in-kansas/. 
Esta revista forma parte del acervo de la Biblioteca Jurídica Virtual del Instituto de Investigaciones Jurídicas de la UNAM http://www.juridicas.unam.mx/ https://biblio.juridicas.unam.mx/bjv https://revistas.juridicas.unam.mx/

ment does refer to an individual right, as decided in a 5-4 ruling. ${ }^{36}$ In this case, the Supreme Court held that the law banning handguns in the District of Columbia was unconstitutional, and violated the Second Amendment. This interpretation of the Second Amendment has determined that citizens have the individual right to possess firearms. Despite being considered a personal right: Justice Scalia agreed that the Second Amendment can be limited and regulated. ${ }^{37}$

Notwithstanding the limitation to the Second Amendment as held by Justice Scalia, others have suggested that the Second Amendment fully protects the individual rights of citizens to purchase, own and carry guns. In this regard, any attempt to regulate firearms is perceived as a violation of the constitutional rights of American citizens. Perhaps the most outspoken organization leading this interpretation is the National Rifle Association. ${ }^{38}$

Founded in 1871, the NRA originally focused on hunting, conservation and marksmanship. ${ }^{39}$ However, after an NRA convention in 1977, it significantly shifted direction. Led by Harlon Carter, a faction of the NRA members took control of the organization and made the defense of the Second Amendment the key to their strategy. Afterwards, the NRA became significantly more outspoken about the right to carry firearms. Consequently, it was after this period that the NRA's mission began to focus on defending a hardline interpretation of the Second Amendment. ${ }^{40}$

With individual donations and substantial financial backing from the gun industry, the NRA has led the gun lobby movement in the U.S. Forty years after its strategic shift, this organization has consolidated its political power and has evolved into one of the most influential interest groups in the U.S. ${ }^{41}$ In fact, the NRA is able to influence crucial political decisions surrounding firearm regulations.

One of the clearest examples of the strength of the NRA occurred in 1996. Following the publication of an academic article that concluded that

36 Legal Information Institute, District Of Columbia V. Heller (No. 07-290), Cornell UnIversity Law School, (Nov. 3, 2015), available at https://wrew.lawe.cornell.edu/supct/cert/07-290.

37 Thomas M. Defrank, Supreme Court Justice Antonin Scalia said that the right to bear arms is not unlimited, and noted that future limitations will have to be decided in future cases, NY DAILY NEws, (Sep. 3, 2014), available at http://wrerenydailynews.com/news/politics/supreme-court-justice-antoninscalia-beararms-unlimited-noted-future-limitations-decided-future-cases-article-1.1124408.

38 Michael Waldman, How the NRA Rewrote the Second Amendment, Politico Magazine, (May. 19, 2014), available at http://wwrw.politico.com/magazine/story/2014/05/nra-guns-secondamendment-106856.

39 Joel Achenbach, Scott Higham \& Sari Horwitz, How NRA's true believes converted a marksmanship group into a mighty gun lobby, The Washington Post, (Jan. 12, 2013), available at https://wrere. washingtonpost.com/politics/how-nras-true-believers-converted-a-marksmanship-group-into-a-mighty-gun-lob by/2013/01/12/51c62288-59b9-11e2-88d0-c4cf65c3ad15_story.html?utm_term=.7b3b9159db52.

$40 \quad$ Id.

41 The Violence Policy Center, Blood Money II, How Gun Industry Dollars Fund the NRA, VIOLence Policy Center, available at http://wrere.vpc.org/studies/bloodmoney2.pdf. 
Esta revista forma parte del acervo de la Biblioteca Jurídica Virtual del Instituto de Investigaciones Jurídicas de la UNAM http://www.juridicas.unam.mx/ https://biblio.juridicas.unam.mx/bjv https://revistas.juridicas.unam.mx/ http://dx.doi.org/10.22201/iij.24485306e.2019.1.13127

guns within a household are a risk factor for homicides in the U.S., ${ }^{42}$ Congressman Jay Dickey (R-AR) managed to advocate for banning all funds to conduct public health research on gun violence. ${ }^{43}$ After this regulation passed with the support of the NRA, the U.S. Center for Diseases Control and Prevention $(\mathrm{CDC})$ halted all health research related to gun violence. To date, despite strong support from academics and physicians, who agree that gun violence research is underfunded, and it should be treated as a public health crisis, efforts to remove this restriction have been futile and unsuccessful. ${ }^{44}$

This has not been the only lobbying victory from the NRA. More recently, the gun lobby managed to prohibit medical professionals from speaking freely to their patients about the risks of gun ownership in the state of Florida, even if there were clear signs that patients were suicidal. This regulation was struck down in $2017 .{ }^{45}$ The NRA has also been able to limit the ability of the $\mathrm{Bu}-$ reau of Alcohol, Tobacco, Firearms and Explosives (ATF) to investigate gun crimes. Backed by the NRA, in 2003, U.S. Representative Todd Tiahrt (RKS) successfully introduced an amendment which prohibited the ATF from disclosing firearm trace data to researchers and the public. This amendment limited law enforcement agencies ability to access data, restricting them to accessing only the information exclusively connected to a specific criminal investigation or prosecution. As a result of this amendment, agencies were impeded from accessing and sharing aggregated data that would allow them to examine patterns of gun trafficking, or to identify gun dealers linked to large numbers of guns used in criminal acts. ${ }^{46}$ This amendment also required the ATF to destroy all records of gun purchases within 24 hours and prohib-

42 Arthur Kellermann et al., Gun Ownership as a Risk Factor for Homicide in the Home, NEJM New England Journal of Medicine (1993).

43 Center for American Progress, Removing Barried and Reinvesting in Public Health Research on Gun Violence, Genter for American Progress, (Mar. 9, 2016), available at https://wrer.americanprogress.org/issues/guns-crime/reports/2016/03/09/132894/removing-barriers-and-reinvesting-inpublic-health-research-on-gun-violence/; Michael Hiltzik, The NRA has blocked gun violence research for 20 years. Let's end its stranglehold on science, THE LOS ANGELES TIMEs (fune 14, 2016), available at http:// wwrw. latimes.com/business/hiltzik/la-fi-hiltzik-gun-research-funding-20160614-snap-story.html.

44 David E. Stark \& Nigam H. Shah, Funding and Publication of Research on Gun Violence and Other Leading Causes of Death, JAMA (2017); Laura Wagner, Gun Violence Should be Treated as a Public Health Crisis, Study Says. NPR News (Jan. 3, 2017), available at http:// wwrenprorg/sections/thetwo-way/2017/01/03/508037642/study-says-gun-violence-should-be-treatedas-a-public-health-crisis.

45 Everytown for Gun Safety, In Blow to the National Rifle Association, Federal Appeals Court Strikes Down Gun Lobby-Backed Florida Doctor Gag Rule That Barred Doctors From Talking With Patients About Guns, Everytown FOR Gun SAFETy, (Feb. 17, 2017), available at https://everytown.org/press/ in-a-blow-to-the-national-rifle-association-federal-appeals-court-strikes-down-gun-lobby-backed-florida-doctor-gag-rule-that-barred-doctors-from-talking-with-patients-about-guns/; James Hamblin, The Question Doctors Can't Ask, The Atlantic, (Aug. 11, 2014), available at https://wrew.theatlantic.com/health/ archive/2014/08/doctors-cant-ask-about-guns/375566/.

46 Giffords Law Cienter to Prevent Gun Violence, Tiahrt Amendments, available at http://lawcenter.giffords.org/gun-laws/federal-law/other-laws/tiahrt-amendments/. 
ited the ATF from requiring gun dealers to submit inventories to law enforcement agencies. However, after organizations such as Mayors Against Illegal Guns campaigned to oppose this amendment, some of these procedures were reversed. ${ }^{47}$ For instance, the ATF regained the right to release aggregate data, and law enforcement agencies recovered some access to trace data. Nonetheless, other restrictions imposed by the Tiahrt Amendment remain an obstacle for law enforcement agencies. In addition, access to data concerning guns used in criminal activities is limited for the public as well as researchers. ${ }^{48}$

Another victory for the gun lobby occurred in 2004, ten years after assault weapons were restricted. After numerous high-profile shootings at the end of the 1980s and early 1990s, the Assault Weapons Ban (AWB) was adopted in $1994 .{ }^{49}$ This legislation included a sunset provision that indicated that the law would expire ten years later (in 2004), unless it was renewed by Congress. Congress did not renew the legislation, ending the ban on assault weapons in September of $2004 .{ }^{50}$ It then became legal for companies to manufacture and for citizens to purchase as well as possess assault weapons in the U.S.

A year after the AWB expired, the NRA had another legal victory. In 2005, the Protection of Lawful Commerce in Arms Act (PLCAA) was signed into law. With some exceptions, this federal law provided immunity from liability to firearm manufacturers and federal gun dealers. ${ }^{51}$

Perhaps the most recent victory of the gun lobby occurred after one of the most horrific incidents in the U.S., when a 20-year-old man used an AR-15 rifle to murder 26 people - including 20 young children - in an elementary school in the state of Connecticut at the end of 2012. Following the massacre, polls showed that public opinion supported gun violence prevention measures. However, the two most important bills introduced after this tragedy did not pass the Senate. ${ }^{52}$ These included the reinstatement of the Assault

47 Gity of Boston, Mayor Menino Joins Bloomberg to Urge Repeal of Tiahrt AmendMENT, available at https://wrere.cityofboston.gov/news/Default.aspx:id=3557.

48 Winnie Stachelberg, Arkadi Gerney and Chelsea Parsons, Blindfolded, and with One Hand Tied Behind the Back, Genter for American Progress, (Mar. 19, 2013), available at https://cdn. americanprogress.org/wpcontent/uploads/2013/03/GunRidersBrief-7.pdf.

49 For example, a case involved the shooting at the Cleveland Elementary School in Stockton California during 1989. The perpetrator fatally shot 5 school children and wounded another 32 others before committing suicide.

50 Giffords Law Center to Prevent Gun Violence, Assault Weapons, available at http://smartgunlaws.org/gun-laws/policy-areas/classes-of-weapons/assault-weapons/. Assault Weapons manufactured before 1994 were legal.

51 Center for American Progress, Immunizing the Gun Industry, CEnTER FOR AMERICAN Progress, (Jan. 15, 2016), available at https://cdn.americanprogress.org/wp-content/uploads/2016/01/14133650/PLCAA.pdf.

52 Meghan Keneally, Four Years After Sandy Hook, Obama Leaves a Legacy of Little Progress on Gun Laws, ABC, (Dec. 14, 2016), available at http://abcnews.go.com/Politics/years-sandy-hook-obamaleaves-legacy-progress-gun/story? id $=44163755$. 
Esta revista forma parte del acervo de la Biblioteca Jurídica Virtual del Instituto de Investigaciones Jurídicas de la UNAM http://www.juridicas.unam.mx/ https://biblio.juridicas.unam.mx/bjv https://revistas.juridicas.unam.mx/ http://dx.doi.org/10.22201/iij.24485306e.2019.1.13127

Weapons Ban and the implementation of universal background checks for buyers on all gun sales. ${ }^{53}$

Perhaps what is most surprising about the NRA is that it can influence decisions to pass or block policies despite support or opposition from the general population. Numerous polls indicate that universal background checks are supported by 85 to 97 percent of Americans, including gun owners. ${ }^{54}$ Other polls suggest that the reinstatement of the assault weapons ban is supported by 67 percent of the U.S. population. ${ }^{55}$ A poll from 2017 shows that 67 percent of U.S. voters oppose the federal ban that limits the GDC's ability to conduct research on gun violence. ${ }^{56}$ This poll also indicates that 60 percent of the U.S. population opposes the gag rule that limits the ability of doctors to discuss guns with their patients. ${ }^{57}$

How is the NRA able to influence legislation without a support from the majority of the population? Aside from its organizational ability, the NRA provides substantial campaign donations to candidates running for public office, including congressional representatives, governors, and even city mayors. ${ }^{58}$ The NRA has also developed a ranking system (from an "A" to "F") in which it evaluates candidates and serving politicians based on their allegiance to the NRA's interpretation of the Second Amendment. ${ }^{59}$ The NRA has also threatened to support rival candidates if politicians do not align with its agenda. ${ }^{60}$

The NRA's impact has been substantial. In 2002, the NRA argued that George W. Bush "owed the Presidency" to the Association's donations and

53 Currently in the U.S., background checks are only mandatory on gun transactions that occur on Federal Firearm Licensees. However, they are not mandatory on internet sales or at gun shows.

54 Mike Lillis, Poll: 92 percent of gun owners support universal background checks, THE HiLL (2014), available at http://thehill.com/blogs/blog-briefing-room/news/211321-poll-most-gun-owners-support-universal-background-checks; Hannah Fingerhut, 5 facts about guns in the United States, PEw REsEARCH CENTER, available at http://wrww.pewresearch.org/fact-tank/2016/01/05/5-facts-about-guns-in-theunited-states/; Quinnipiac University, U.S. Support For Gun Control Tops 2-1, Highest Ever, Quinnipiac University National Poll Finds," QUINNIPIAC UnIVERsity, available at https://poll.qu.edu/national/ release-detail?ReleaseID $=2521$.

55 Quinnipiac University, U.S. Support For Gun Control Tops 2-1, Highest Ever, Quinnipiac University National Poll Finds," QuinniPIAC UNIVERsity, available at https://poll.qu.edu/national/releasedetail?Release $I D=2521$.

56 Guns Down, New Poll: Americans Believe Fewer Guns Will Keep us Safer, Arms Down, (June 14, 2017), available at https://gunsdownamerica.org/new-poll-safety-over-gun-rights/.

57 Id.

58 Aaron Williams, Has your U.S. Congressperson received donations from the NRA? THE WASHINGTON Post, (June 21, 2016), available at https://wrere.washingtonpost.com/graphics/national/nra-donations/.

59 National Rifle Association-Political Victory Fund, Grades and Endorsement, available at https://wrew.nrapvf.org/grades/.

60 Josh Israel, NRA Threatens Senators Who Support Campaign Finance Disclosure, THINK ProGRESS, (July 13, 2012), available at https://thinkprogress.org/exclusive-nra-threatens-senators-who-supportcampaign-finance-disclosure-6b086e9fef2d. 
Esta revista forma parte del acervo de la Biblioteca Jurídica Virtual del Instituto de Investigaciones Jurídicas de la UNAM http://www.juridicas.unam.mx/ https://biblio.juridicas.unam.mx/bjv https://revistas.juridicas.unam.mx/

support. ${ }^{61}$ Recently, the NRA spent close to 30 million dollars backing President Donald Trump's campaign, and later publicly supported his presidency and proposals. ${ }^{62}$ In response, Trump became the first sitting president to address the country's largest gun lobby in more than three decades, speaking at the NRA's Annual Meeting in April 2017. During his address, he pledged to support the goals and mission of this organization. ${ }^{63}$

Available evidence suggests that the NRA exerts substantial political influence over gun regulations. With their grip on policy makers, this organization has shown its ability to lobby for laws and policies that follow its interpretation of the Second Amendment.

The NRA, however, has not remained unchallenged. After the mass shootings in Connecticut at the end of 2012, several organizations in the U.S. such as Everytown for Gun Safety, Giffords and the Brady Campaign to Prevent Gun Violence have advocated for stronger gun laws. The major successes of these organizations have occurred at the state level. Since December 2012 and as of October 2017, states have enacted more than 200 laws that are stronger on gun control. ${ }^{64} 11$ states have strengthened their background check systems, and six have implemented local policies that require lost and stolen guns be reported to authorities. ${ }^{65}$ Five states have enacted laws banning assault weapons, and 27 more have passed regulations addressing the use of guns by domestic abusers. ${ }^{66}$

The result of this contrasting phenomenon is a polarized country, as evident in the differences in state gun laws. ${ }^{67}$ Some states have weakened their gun laws, while others have strengthened their local policies. The Law Center to Prevent Gun Violence has indicated that the states with the strictest gun laws as of 2017 are: California, New Jersey, Connecticut, Massachusetts, New York, Maryland, Hawaii, Illinois, Rhode Island and Washington. By contrast, the states with the

61 Associated Press, Bush Owes Presidency to NRA, NRA Says, Los Angeles Times, (2002), available at http://articles.latimes.com/2002/apr/28/newes/mn-40519.

62 The New York Time's editorial board, Even as President, Donald Trump Panders to the N.R.A., The New York Times, (2017), available at https://wrerc.nytimes.com/2017/04/29/opinion/even-aspresident-donald-trump-panders-to-the-nra.html?__r=0.

63 Kira Lernes, Trump will be the first president to address the radicalized NRA, THInK Progress, (2017), available at https://thinkprogress.org/trump-nra-speech-c46de8cfc5fo.

64 Giffords Law Center to Prevent Gun Violence, State Legislative Trends since Newtown; Newsweek, (2017), available at http://wrerw.newsweek.com/sandy-hook-anniversary-guncontrol-laws-failed-747415; Giffords Law Center to Prevent Gun Violence, Annual Gun LAW SCORECARD 2017 , available at http://lawcentergiffords.org/scorecard/.

65 Giffords Law Center to Prevent Gun Violence, State Legislative Trends since Newtown.

66 Id; Lois Beckett, 10 gun violence prevention victories since Sandy Hook, THE GUARDIAN, (2017), available at https://wrere.theguardian.com/us-news/2017/nov/13/10-gun-violence-prevention-victoriessince-sandy-hook.

67 National Black Caucus of State Legislators, State Gun Laws More Polarized THAN Ever, available at http://wrercenbcslorg/index.php/public-policy/state-issues/state-issues-archive/ item/1161-state-gun-lawes-more-polarized-than-ever. 
Esta revista forma parte del acervo de la Biblioteca Jurídica Virtual del Instituto de Investigaciones Jurídicas de la UNAM http://www.juridicas.unam.mx/ https://biblio.juridicas.unam.mx/bjv https://revistas.juridicas.unam.mx/ http://dx.doi.org/10.22201/iij.24485306e.2019.1.13127

most permissive gun laws are Mississippi, Missouri, Kansas, Arizona, Idaho, Wyoming, Alaska, Louisiana, West Virginia and Vermont. ${ }^{68}$ As detailed in the following section, there are significant differences in terms of gun violence between these two contrasting groups of states. The following section will discuss the existing evidence (outcomes) concerning permissive gun laws in the U.S.

\section{Impacts of Permissive Gun Laws in the U.S.}

To date, the NRA's successful efforts to maintain permissive gun laws have resulted in an increase of firearm production and gun violence in the U.S. The U.S. produced close to 3,650,000 firearms in 2006, by 2016 this figure had increased to close to $11,500,000 .^{69}$ Imports have also increased, from around 2,400,000 in 2006 to 5,100,000 in $2016 .^{70}$ As a result of this growth there is almost one firearm per citizen, and the U.S. has by far the highest rate of gun ownership in the world..$^{71}$

\section{GRAPH 1: RATE OF GUN HOMICIDE PER 100,000 INHABITANTS across High-Income Countries, 2010}

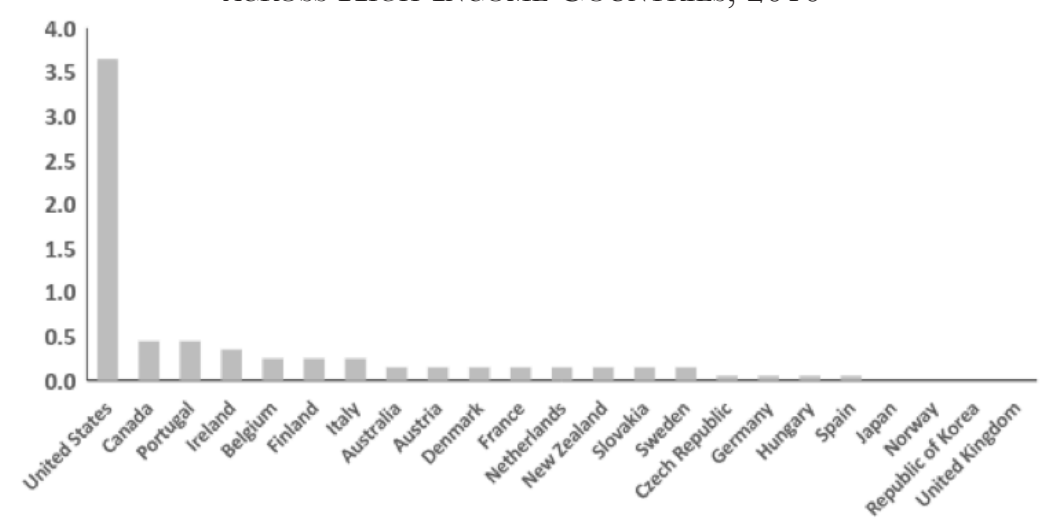

Source: Erin Grinshteyn \& David Hemenway, Violent Death Rates: The US compared with Other High Income OECD Countries, 2010, 219 The American Journal of Medicine 3, 266273 (2016).

68 Law Center to Prevent Gun Violence, 2017 Annual Gun law Scorecard, available at http://lawcenter.giffords.org/scorecard/.

69 Bureau of Alcohol, Tobacco, Firearms and explosives (ATF), Firearms Commerce in the United States 2017 (2017), available at https://wrwe.atf.gov/resource-center/docs/undefined/firearms-commerce-united-states-annual-statistical-update-2017/download; Bureau of Alcohol, Tobacco, Firearms and explosives (ATF), Annual Firearms Manufacturing and Export Report (2016), available at https:// wwre.atf.gov/about/docs/undefined/afmer2016webreport508pdf/download.

70 Id.

71 Small Arms Survey, Estimating Civilian Owned Firearms, Small Arms Survey, available at http://wrere.smallarmssurvey.org/fileadmin/docs/A-Yearbook/2007/en/full/Small-Arms-Survey-2007-Chapter-02-EN.pdf. 
Esta revista forma parte del acervo de la Biblioteca Jurídica Virtual del Instituto de Investigaciones Jurídicas de la UNAM http://www.juridicas.unam.mx/ https://biblio.juridicas.unam.mx/bjv https://revistas.juridicas.unam.mx/

The U.S. has a gun homicide rate that is 25 times higher than other developed countries. ${ }^{72}$ If only young Americans, ages 15 to 24, are counted, the rate is 49 times higher in the U.S. than in other developed nations. ${ }^{73}$ However exceptional, these figures only indicate a part of the story. Every day, approximately 91 people are killed with a gun in the U.S., and another 222 are injured. ${ }^{74}$ In 21 states, more people are killed with a gun every year than in vehicle related accidents. ${ }^{75}$ The accessibility of guns also increases risks of accidental deaths. Every day a person is accidentally shot and killed in the United States, while 46 are accidentally injured. ${ }^{76}$ In fact it is more likely one would be shot by a toddler than be killed in a terrorist attack in the US. ${ }^{77}$

The availability of firearms due to permissive gun policies has consequences that are completely unrelated with the notion of self-defense. For instance, the U.S. has an alarming rate of firearm suicides, eight times higher than other developed countries. ${ }^{78}$ On average a firearm suicide occurs every 26 minutes in the U.S. ${ }^{79}$ Proponents of permissive gun laws often argue that guns are a mere tool (i.e. people would commit suicide anyway), and that other factors should be addressed to mitigate suicide rates. However, evidence indicates that while other factors are important, access to guns plays a significant role. A study conducted in 8 states concluded that firearms were the most fatal method of attempting suicide ${ }^{80}$ While 30 percent of suicide attempts via other methods resulted in a fatality, 83 percent of suicide attempts

72 Erin Grinshteyn \& David Hemenway, Violent Death Rates: The US compared with Other High-Income OECD Countries, 2010, 219 The American Journal of Medicine 3, 266-273 (2016).

73 Id.

74 Analysis of 2007-2016 data from Center for Disease Control and Prevention, Injury Prevention \& Control: Data \& Statistics (WISQARS): Fatal Injury Data, available at https://wrere.cdc.gov/injury/wisqars/fatal.html; Center for Disease Control and Prevention, Injury Prevention \& Control: Data \& Statistics (WISQARS): Nonfatal Injury Data, available at https://wrere.cdc.gov/injury/wisqars/nonfatal.html.

75 Violence Policy Center, Gun Deaths Surpass Moto Vehicle Deaths in 21 States and the District of Columbia, Violence Policy Center, (2016), available at http://wrwrevopcorg/press/gun-deathssurpass-motor-vehicle-deaths-in-21-states-and-the-district-of-columbia/.

76 Analysis of 2007-2016 data from Center for Disease Control and Prevention, Injury Prevention \& Control: Data \& Statistics (WiSQARS): Fatal Injury Data, available at https://webappa.cdc.gov/sasweb/ncipc/mortrate.html; Center for Disease Control and Prevention, Injury Prevention \& Control: Data \& Statistics (WISQARS): Nonfatal Injury DATA, available at https://werere.cdc.gov/injury/reisqars/nonfatal.html.

77 Todd Miller, The Freakonomics of Extreme Extreme Vetting, The Huffington Post (2016), available at http://wererre.huffingtonpost.com/todd-r-miller/the-freakonomics-of-extre_b_11821634.html.

78 Erin Grinshteyn \& David Hemenway, Violent Death Rates: The US compared with Other High-Income OECD Countries, 2010, 219 The American Journal of Medicine 3, 266-273 (2016).

79 Analysis of 2007-2016 data from Center for Disease Control and Prevention, Injury Prevention \& Control: Data \& Statistics (WISQARS): Fatal Injury Data, available at https://webappa.cdc.gov/sasweb/ncipc/mortrate.html.

80 Rebecca Spicer and Ted Miller, Suicide Acts in 8 States: Incidence and Case Fatality Rates by Demographics and Method, 90 American Journal of Public Health 12, 1885 (2000). 
Esta revista forma parte del acervo de la Biblioteca Jurídica Virtual del Instituto de Investigaciones Jurídicas de la UNAM http://www.juridicas.unam.mx/ https://biblio.juridicas.unam.mx/bjv https://revistas.juridicas.unam.mx/

with a firearm had the same result. ${ }^{81}$ In other words, firearms, even if they are considered only a tool to commit suicide, play an important role in the overall lethality of suicide attempts. To further support this argument, a 2016 study found that states with higher levels of gun ownership were strongly associated with the highest rates of firearm suicides among both women and men. ${ }^{82}$

Other violent outcomes should also be included in an assessment of the permissive gun laws in the U.S. For instance, evidence suggests mass shootings, defined as incidents where four or more people are fatally shot, are deadlier and more frequent. While these incidents occurred every 200 days prior to 2011, since then they occur every 64 days. ${ }^{83}$ In June 2015, a young white male fatally shot eight African Americans in a church in Charleston, South Carolina. A year later, a mass shooting occurred in the city of Orlando when a man entered a night club and opened fire at the crowd. As a result of this attack, 49 people were fatally shot and another 53 were injured.$^{84}$ In 2017, the United States had its deadliest mass shooting in modern history. A man used a semiautomatic firearm to shoot at people attending a country music concert in Las Vegas, Nevada. From his hotel window, the perpetrator killed 58 people and injured close to 500 more. ${ }^{85}$ These are extreme but not isolated cases. Mass shootings have taken place in colleges, movie theaters, churches, and even in schools. Moreover, if the definition of mass shooting involves four or more people shot, fatally or not, approximately 1,000 mass shootings occurred in a period of 1,260 days. ${ }^{86}$

An argument often cited by the NRA is that armed civilians with guns can rapidly stop mass shootings. ${ }^{87}$ The NRA often refers to these armed civilians as "good" guys with guns. ${ }^{88}$ According to this rationale, it is important

\section{Id.}

82 Michael Siegel and Emily Rothman, Firearm Ownership and Suicide Rates Among US Men and Women, 1981-2013, 106 American Journal of Public Health 7, 1316-1322 (2016).

83 Amy Coheb, Deborah Azrael, \& Matthew Miller, Rate of Mass Shootings Has Tripled Since 2011, Harvard Research Shows, Mother Jones, (2014), available at http://www.motherjones.com/politics/2014/10/mass-shootings-increasing-harvard-research/. Authors of this article are scholars from the Harvard School of Public Health and Northeastern University. The authors wrote this article based on their research.

84 BBC News, Orlando nightclub shooting: How the attack unfolded, BBC News (2016), available at http://wwre.bbc.com/news/world-us-canada-36511778.

85 BBC News, Las Vegas Shooting - What we Know so Far, BBC News (2017), available at http:// wrww.bbc.com/news/world-us-canada-41471242.

86 The Guardian, 1,000 mass shootings in 1,260 days: this is what America's gun crisis looks like, The GuARDian, (2015), available at https://wrewetheguardian.com/us-news/ng-interactive/2015/ oct/02/mass-shootings-america-gun-violence.

87 Rachel Tropp, The "Good Guy With a Gun" Myth, Harvard Political Review (2016), available at http://harvardpolitics.com/united-states/good-guy-gun-myth/; Matthew Chapman, The NRA's "Good Guy/Bad Guy" Argument is Fatal Stupidity, HufFington POst, July 12, 2016, available at http://wrwr.huffingtonpost.com/matthew-chapman/the-fatal-stupidity-of-th_b_10940338.html.

88 Id. 
Esta revista forma parte del acervo de la Biblioteca Jurídica Virtual del Instituto de Investigaciones Jurídicas de la UNAM http://www.juridicas.unam.mx/ https://biblio.juridicas.unam.mx/bjv https://revistas.juridicas.unam.mx/

to allow gun possession in public places such as bars and churches so that an armed civilian can defend potential victims in case of an attack. One of the most recent cases in favor of this argument occurred on November 2017, when a man fatally shot 26 people and injured many more at church in Sutherland Spring, Texas. The case rapidly became popular amongst gun rights activists as the perpetrator was shot by an armed civilian. ${ }^{89}$

While there have been cases where civilians do stop shooters, these are rather the exception and occur after multiple people have been shot. A study of 63 mass shootings concluded that not even one attack was stopped by armed individuals. ${ }^{90}$ Expanding this sample further to 160 mass killings between 2000 to 2013, an FBI study showed that only one aggressor was stopped by an armed civilian. ${ }^{91}$ In contrast, the Violence Policy Center found that "good" guys with concealed carry licenses have perpetrated 31 mass shootings since $2007 .{ }^{92}$ The costs behind this argument appears to exceed the possible benefits. Additionally, armed citizens can worsen the outcomes of mass shootings. In 2011, for example, an armed citizen almost shot the wrong person during the mass shooting that injured Congresswoman Gabrielle Giffords in Tucson, Arizona. ${ }^{93}$

The NRA has also argued that citizens with concealed firearms prevent crimes. In this context, it often cites a study written by John Lott. In his work, Lott argues that the implementation of concealed carry laws allowing citizens to carry firearms were associated with a reduction in violent crime during the 1990s. ${ }^{94}$ Nonetheless, when researchers from Stanford and Johns Hopkins University updated this research, they concluded that concealed carry laws were not associated with lower rates of violent crimes, rather, they were linked to a 15 percent increase in violent crimes. ${ }^{95}$ Furthermore, a 2005 re-

89 Dakin Andone, Kayle Hartung and Darran Simon, At least 26 people killed in shooting at Texas Church, CNN, (2017), available at https://wwre.cnn.com/2017/11/05/us/texas-church-shooting/ index.html.

90 Mark Follman, More Guns, More Mass Shootings-Coincidence, Mother Jones, (2012), available at http://wrew.motherjones.com/politics/2012/09/mass-shootings-investigation/.

91 Federal Bureau of Investigation, A Study of Active Shooter Incidents in the UNITED STATES BETWEEN 2000 AND 2013, available at https://wrwo.fbi.gov/news/stories/fbi-releasesstudy-on-active-shooter-incidents.

92 Violence Policy Center, Mass Shootings Committed by Concealed Carry Killers, Violence PolICY CENTER, available at http://concealedcarrykillers.org/.

93 Elspeth Reeve, Armed Hero in Giffords Shooting Almost Shot the Wrong Guy. The AtLantiC (2011), available at https://wrew.theatlantic.com/politics/archive/2011/01/armed-hero-in-giffords-shooting-almost-shot-the-wrong-guy/339205/.

94 John Lott, More Guns, Less Crime, University of Chicago Press, Third Edition; John Lott and David Mustard, Crime, Deterrence, and Right-to-Carry Concealed Handguns, 26 Journal OF LEGAL STUDies 1 (1997).

95 John Donohue, Abhay Aneja \& Kyle Webe, Right-to-carry gun laws and Violent Crime: A Comprehensive Assessment Using Panel Data and a State-Level Synthetic Controls Analysis, The NATIONAL BurEaU OF ECONOMIC RESEARCH, available at http://wwwenber.org/papers/w23510. 
Esta revista forma parte del acervo de la Biblioteca Jurídica Virtual del Instituto de Investigaciones Jurídicas de la UNAM http://www.juridicas.unam.mx/ https://biblio.juridicas.unam.mx/bjv https://revistas.juridicas.unam.mx/ http://dx.doi.org/10.22201/iij.24485306e.2019.1.13127

port from the National Research Council of the National Academies of Sciences, Engineering, and Medicine determined that it is not possible to reach any conclusion about the causal link between the passage of concealed carry laws and crime rates. ${ }^{96}$

Proponents of lax gun regulations often argue that the benefits of armed civilians outweigh the costs. For example, a 1992 study by Kleck and Getz suggested that up to 2,500,000 crimes in the U.S. were prevented by citizens armed with guns, suggesting that firearms are used more often to prevent a crime than to commit one. ${ }^{97}$ Nevertheless, existing evidence points to fallacies in this argument. A 1997 report criticized Kleck's and Getz's methodology by suggesting bias issues due to problems with social desirability and telescoping. ${ }^{98}$ Furthermore, data from the National Crime Victimization Survey suggest the probability of being injured during a robbery was the same when victims did nothing in comparison to victims that used guns. ${ }^{99}$ In other words, there are no clear advantages of using a firearm during a robbery. This research also shows that firearms are rarely used for self-defense. In fact, out of all crimes committed between 2007 and 2011 in the U.S., only 0.9 percent involved a victim able to use a gun. ${ }^{100}$

The Violence Policy Center has recently found that for every justified gun homicide that occurs in self-defense in the U.S., more than 34 people are feloniously murdered with a gun. ${ }^{101}$ Firearms at home increase the risks of suicide and homicide. ${ }^{102}$ Evidence suggests that, when available, guns are more likely to be used against a member of the household than to be used for self-defense against an offender. ${ }^{103}$

96 National Academies of Sciences Engineering Medicine, Firearms and Violence: A CRITICAL REVIEw CHAPTER 6 (2005), available at https://wrere.nap.edu/read/10881/chapter/8.

97 Gary Kleck \& Marc Gertz, Armed Resistance to Crime: The Prevalence and Nature of Self-defense with a Gun. Journal of Criminal Law ANd CRiminology 86 (1995).

98 David Hemenway, Survey Research and Self-Defense Gun Use: An Explanation of Extreme Overestimates, Journal of Criminal Law and Criminology 87 (1997); Evan DeFilippis, Debunking the Defensive Gun Use Myth, ARMED wITH REASOn, (2015), available at https:/ wrwerearmedwithreason.com/ debunking-the-defensive-gun-use-myth/. Social desirability bias refers to tendencies of respondents to answer favorably by others. If you purchased a gun for example, you want to appear favorably by saying that you have used that gun. Telescoping refers to a displacement of an event. For this case, respondents may believe that an event is more recent than what it is.

99 David Hemenway \& Sara Solnick, The epidemiology of self-defense gun use: Evidence from the National Crime Victimization Survey 2007-2011, 79 Preventrve Medicine, 22-27 (2016).

$100 \quad I d$.

101 Violence Policy Genter, Firearm Fustifiable Homicides and Non-Fatal Self-Defense Gun Use, Violence Policy Center (2017), available at http://wrercevpc.org/studies/justifiable17.pdf.

102 Andre Anglemyer, Tara Horvath \& George Rutherford, The Accessibility of Firearms and Risk for Suicide and Homicide Victimization Among Household Members: A Systematic Review and MetaAnalysis, 160 Annals of Internal Medicine, 101-110 (2014).

103 Deborah Azrael \& David Hemenway, 'In the Safety of your own home': results from a national survey on gun use at home, 50 Social Saience ANd Medicine, 285-291 (2000). 
Another argument is that criminals choose gun free zones to commit crimes as well as mass shootings, and therefore having more available guns will stop these unfortunate incidents. ${ }^{104}$ However, evidence does not support these claims. A study of 111 mass shooting that occurred between 1966 and 2015 in the U.S. revealed that only 18 occurred in places where carrying guns was restricted for civilians. ${ }^{105}$ A report from Everytown for Gun Safety found that out of the mass shootings committed between 2009 and 2016, only 10 percent occurred in gun free zones. ${ }^{106}$

Several examples suggest that perpetrators of crime are not always deterred by armed individuals. These examples include cases of ambushes against police officers in the U.S. These attacks debunk the arguments that criminals select unarmed victims, and suggest that given the element of surprise, armed criminals can cause serious harm before being stopped by armed individuals. Recently, for example, five armed police officers were fatally shot during an ambush in Dallas, Texas, where another seven civilians were injured. ${ }^{107}$ During this incident, the aggressor was involved in a standoff with armed police forces that lasted four hours. Contrary to the gun activists' discourse, this is not an isolated case, as there have been numerous incidents where police officers are attacked, despite being armed with guns and being explicitly trained to manage violent criminals. ${ }^{108}$

Easier access to guns, facilitated by permissive gun laws can trigger additional costs to law enforcement institutions. A study looked at gun ownership and rates of police officers killed with a firearm across the 50 U.S. states. The analysis concluded that for each 10 percent increase in gun ownership, there were ten more police officers killed with a gun. ${ }^{109}$ According to the FBI, attacks against police officers can occur in diverse instances. For example, they can occur

104 John Lott, Gun-free zones easy targets for would-be killers, USA TODAY, February 9, 2017, at https://wwwe.usatoday.com/story/opinion/columnists/2017/02/09/john-lott-gun-free-zones-easy-targetswould--killers/97645622/.

105 Louis Klarevas, Rampage Nation: Securing America from Mass Shootings. Amherst, NY: ProMETHEUs BoOKs, 2016.

106 Everytown for Gun Safety, Mass Shootings in the United States: 2009-2016, EverYTOwN FOR Gun SAFETY, April 11, 2017, at https://everytownresearch.org/reports/mass-shootings-analysis/.

107 Joel Achenbach, William Wan, Mark Berman \& Moriah Balingit, Five Dallas police officers were killed by a lone attacker, authorities say, Washington Post, July 8, 2016, at https://wwrw. washingtonpost.com/news/morning-mix/wp/2016/07/08/like-a-little-war-snipers-shoot-11-police-offcers-during-dallas-protest-march-killing-five/?utm_term =.2a3d54081d26.

108 See for example Mark Berman \& Adam Goldman. Police: Officers in Baton Rouge were 'targeted and assassinated,' The Washington Post, July 18, 2016, at https://wrewewashingtonpost. $\mathrm{com} /$ news/post-nation/wp/2016/07/18/details-emerge-about-suspected-baton-rouge-gunman-who-hadendorsed-violence-in-online-videos/?utm_term $=.5 a 0 a c 85626 \mathrm{bf}$.

109 David Swedler et al, Firearm Prevalence and Homicides of Law Enforcement Officers in the United States, 105 American Journal of Public Health 10, 2042-2048 (2015). 
Esta revista forma parte del acervo de la Biblioteca Jurídica Virtual del Instituto de Investigaciones Jurídicas de la UNAM http://www.juridicas.unam.mx/ https://biblio.juridicas.unam.mx/bjv https://revistas.juridicas.unam.mx/ http://dx.doi.org/10.22201/iij.24485306e.2019.1.13127

when officers attend domestic violence disputes, while they serve an arrest, or even while conducting a simple traffic stop for speeding. ${ }^{10}$

Permissive gun laws trigger a complex phenomenon that increases the risks of fatal encounters between police officers and regular citizens regardless of who end up being shot. A 2017 study found that permissive gun laws are an important factor in people being shot by a police officer. The study concluded that individuals living in states with stronger gun laws were 51 percent less likely to be shot by police than those individuals living in states with weaker gun laws. The rationale is that police officers either encounter more armed individuals or are aware that they are more prone to encounter armed individuals in states with permissive gun laws, and would be more likely to react with fatal force than those police officers in states where guns are scarce. ${ }^{111}$

The existence of permissive gun laws also provokes several negative outcomes associated with social violence. The availability of firearms, for example, plays a major role on fatal cases of domestic violence. A study from the Center for American Progress found that more than 50 percent of intimate partner homicides of women in the U.S. are committed with a gun. ${ }^{112}$ In fact, when a gun is available in a domestic violence situation, the risk of homicides against women increases by 500 percent. ${ }^{113}$ In a similar manner, the aforementioned study from Everytown for Gun Safety also found that the majority of mass shootings in the U.S. take place in households during a domestic violence dispute. ${ }^{114}$ Altogether, this evidence suggests that guns that are originally purchased for self-defense have a high risk of being used against women in their own home.

Permissive gun laws also increase the costs associated with interpersonal conflicts between members of a community that would not be as violent otherwise. One of the most common examples is school shootings, which would not occur if guns were not available to students. High availability of guns has made school shootings a major concern for parents, teachers and students in the U.S. These concerns and fears are altogether reasonable.

Some school shootings have received major public attention. On February 2018, a 19-year-old man fatally shot 17 people and injured 17 more at Mar-

110 Federal Bureau of Investigations, Law Enforcement Officers Killed and AsSAUlted. Uniform Crime Reporting, available at https://ucr.fbi.gov/leoka.

111 Aaron Kivisto, Bradley Ray \& Peter Phalen, Firearm Legislation and Fatal Police Shootings in the United States, 107 American Journal of Public Health 7, 1068-1075 (2017).

112 Arkadi Gerney \& Chelsea Parsons, Women Under the Gun, Center for American ProgRESs, June 1, 2014, available at https://cdn.americanprogress.org/wp-content/uploads/2014/06/GunsDomestic Violencereport.pdf.

113 Jane Koziol-Mclain et al, Risk Factors for Femicide in Abusive Relationships: Results from a multisite case control study, 21 ViOLENCE AND ViCTIMs, 3-21 (2006).

114 Everytown for Gun Safety, Mass Shootings in the United States: 2009-2016, EverYTOwN FOR GUN SAFETY, April 11, 2017, available at https://everytownresearch.org/reports/mass-shootingsanalysis/. Last accessed May $31^{\text {st }}, 2018$. 
Esta revista forma parte del acervo de la Biblioteca Jurídica Virtual del Instituto de Investigaciones Jurídicas de la UNAM http://www.juridicas.unam.mx/ https://biblio.juridicas.unam.mx/bjv https://revistas.juridicas.unam.mx/

jory Stoneman Douglas High School in Florida. ${ }^{115}$ This incident has raised awareness on gun violenceand has sparked March for Our Lives, a movement that advocates for stronger gun laws. ${ }^{116}$ Nonetheless, there are numerous similar incidents across all the U.S. According to data from Everytown for Gun Safety, there were at least 316 incidents of gun fire from January 2013 to June 2018. ${ }^{117}$ In this regard, the modus operandi of school shooters deserves particular attention as the majority of these shootings are perpetrated by minors, and in more than half of these shootings, minors brought the gun from home. ${ }^{118}$ These incidents have a tremendous impact on student performance and mental health. A recent empirical study found that school shootings resulting in a fatality reduce school enrollment, cause students to become depressed, and reduce standardized test scores by five percent. ${ }^{119}$

Existing evidence also suggests that the availability of guns can expand the severity (mortality and morbidity) of the resulting outcome in cases associated with random and unplanned conflicts linked to social violence. For instance, road rage incidents between citizens carrying guns are a growing concern across the U.S. According to data from The Trace, while there were 247 road rage incidents involving a gun in 2014, this figure rose to 621 by 2016. In 40 percent of these incidents, someone was either injured or killed with a gun. ${ }^{120}$

As previously discussed, permissive gun laws are associated with higher levels of gun ownership. With higher levels of gun ownership, the risk of gun thefts also increases. Privately owned firearms are stolen with high frequency in the United States: a 2017 study revealed that between 300,000 and 600,000 firearms are stolen every year. ${ }^{121}$ This phenomenon is a response to

115 Eizabeth Chuck, Alex Johnson and Corky Siemaszko, 17 killed in mass shooting at high school in Parkland, Florida, NBC News, February 15, 2018, at https://wrerr.nbcnewes.com/neres/usnewes/police-respond-shooting-parkland-florida-high-school-n848101.

116 Ariel Edwards-Levy, How Viewes On Guns Have Changed Since the Parkland Shooting, THE Huffington Post, April 30, 2018, at https://wrerre.huffingtonpost.com/entry/howe-viewes-on-gunshave-changed-since-the-parkland-shooting_us_5ae78a59e4b055fd7fcedb48; Jennifer Angiesta, CNNN Poll: Seven in 10 favor tighter gun lawes in wake of Parkland shooting, CNN PoLITICS, February 25, 2018, available at https://wrerr.cnn.com/2018/02/25/politics/cnn-poll-gun-control-support-climbs/ index.html; Dakin Andone, What you should know about the March for Our Lives, GNN, available at https://wrerre.cnn.com/2018/03/21/us/march-for-our-lives-explainer/index.html.

117 Everytown for Gun Safety, Gunfire on school grounds in the United States, EverYTOWn FOR Gun SAFETY, available at https://everytownresearch.org/school-shootings/(Last accessed June 5, 2018).

118 Everytown for Gun Safety, Analysis of School Shootings, Everytown for Gun SAfety, December 31, 2015, available at https://everytownresearch.org/reports/analysis-of-school-shootings/.

119 L.-P. Beland \& D. Kim, The Effect of High School Shootings on Schools and Student Performance, 38 Educational Evaluation and Policy Analysis 113-126 (2015).

120 Aviva Shen, When the Driver Who Just Cut You Off Also Has a Gun, The Trace, April 10, 2017, at https://werere.thetrace.org/2017/04/road-rage-shootings-guns/.

121 Brian Freskos, Guns are Stolen in America up to Once Every Minute. Owners who leave their weapons in cars make it Easy for Thieves, THE TRACE, December 21, 2016, at https://wrerce.thetrace. org/2016/09/stolen-guns-cars-trucks-us-atlanta/. 
Esta revista forma parte del acervo de la Biblioteca Jurídica Virtual del Instituto de Investigaciones Jurídicas de la UNAM http://www.juridicas.unam.mx/ https://biblio.juridicas.unam.mx/bjv https://revistas.juridicas.unam.mx/

the opportunity structure of firearm availability, a phenomenon called "target backcloth" by criminologists (e.g. the spatial opportunity structure of crime sites). According to this argument, if guns are available in vehicles, criminals would target vehicles knowing or seeing that a gun is inside. A recent investigation found that after firearms were allowed to be carried in automobiles in the state of Tennessee, the number of stolen firearm increased significantly. ${ }^{122}$ In a similar manner, some of the risk factors that facilitate gun theft include owning multiple guns, unsafe storage and carrying guns in public. ${ }^{123}$

Other states have adopted more extreme self-defense measures offering substantial lessons for other states and countries, such as Mexico itself. Florida, for example, adopted a law called "Stand Your Ground" in which individuals who believe they are under threat of death or injury can use deadly force in the street without the need to retreat. ${ }^{124}$ As a result of this law, homicides in Florida increased significantly. A 2016 study concluded that, because of this new policy, gun homicide rates in Florida increased 32 percent while overall homicide rates increased 24 percent. ${ }^{125}$ Other studies found that states that enacted similar laws presented an increase of eight percent in homicides. ${ }^{126}$

Another issue that deserves attention in this discussion is the fact that states with more permissive gun laws and higher levels of gun ownership tend to illegally export more crime guns to other states. For instance, 74 percent of guns used in crimes in New York, a state with strong gun laws, originated in states with weaker gun laws such as Pennsylvania, Georgia, Florida and North Carolina. ${ }^{127}$ A 2016 analysis by the Center for American Progress found a strong correlation between a states' rate of crime gun exports and the strength of the states' gun laws. ${ }^{128}$ This suggests that gun diversion to criminal networks is more likely to occur in states with more permissive gun laws,

122 Adrian Mojica, Tennessee gun owners unintentionally helping criminal obtain weapons., FOX17 News, November 23, 2016, at http://fox17.com/news/local/tennessee-gun-owners-unintentionallyhelping-criminals-obtain-weapons.

123 David Hemenway, Deborah Azrael \& Matthew Miller, Whose guns are stolen? The epidemiology of Gun theft victim, 4 InJury EPIDEMIOLOGy (2017).

124 Chelsea Parsons, Jeb Bush's License to Kill. Center for American Progress July 28, 2015, available at https://cdn.americanprogress.org/wp-content/uploads/2015/07/28193014/BushStandYourGround-brief-FINAL4.pdf.

125 David Humphreys, Antonio Gasparrini \& Douglas Wiebe, Evaluating the Impact of Florida's "Stand Your Ground" Self-Defense Law on Homicide and Suicide by Firearm, 177 Jama InTERn MeD 1, 44-50 (2017).

126 Cheng \& Mark Hoekstra, Does Strengthening Self-Defense Law Deter Crime or Escalate Violence? Evidence from Expansions to Castle Doctrine, 48 Journal of Human Resource 3, 821-854 (2013).

127 German Lopez, Almost 74\% of guns used in New York crimes come from states with weaker gun laws Vox, October 26, 2016, available at https://wwrw.vox.com/policy-and-politics/2016/10/26/13418208/guns-new-york-iron-pipeline.

128 Chelsea Parsons \& Eugenio Weigend, America under fire. CEnTER FOR AMERICAN Progress October 11, 2016, available at https://cdn.americanprogress.org/wp-content/uploads/2016/10/11100940/AmericaUnderFire-report.pdf. 
generating negative externalities not only in these particular places, but also in surrounding areas.

All of these violent situations also generate economic costs. In this regard, research from the GDC reported that in 2010 the cost of firearm related deaths in the U.S. totaled $\$ 41$ billion. ${ }^{129}$ A more recent and comprehensive study included not only the costs of deaths, but also of hospitalizations and reductions in job productivity, finding that U.S. citizens paid out $\$ 229$ billion due to gun violence in 2015. ${ }^{130}$ To put this figure in perspective, it is more than the economic costs of obesity in the U.S., and $\$ 55$ billion more than Apple's revenue in 2012. ${ }^{131}$

The evidence reviewed thus far suggests that the implementation of permissive gun laws is associated with an escalation of violence, incurring mental, social and financial costs. But what happens if we evaluate the opposite effect, analyzing the cases where gun laws are being strengthened.

Research conducted by Everytown for Gun Safety found that states that implemented universal background checks had rates of intimate partner gun homicides that were 46 percent lower than those states that did not implement such a measure. ${ }^{132}$ This study also found that gun suicides were 48 percent lower in those same states. ${ }^{133}$

Similarly, researchers from Johns Hopkins University analyzed the impact of state permit requirements, including background checks, before purchasing a gun, finding that when Connecticut implemented this requirement, gun homicides decreased by 40 percent. ${ }^{134}$ When the state of Missouri removed such requirement and firearms became more accessible, gun homicides increased by 26 percent. ${ }^{135}$ In other words, gun homicides increase as firearms become more available, and they decrease when tougher restrictions are implemented.

129 Centers for Disease Control and Prevention, Data \& Statistics: Cost of Injury REPORTs, available at https://wisqars.cdc.gov:8443/costT/cost_Part1_Intro.jsp.

130 Mark Follman, Julia Lurie, Jaeah Lee \& James West, The True Cost of Gun Violence in America, Mother Jones, April 15, 2015, available at http://www.motherjones.com/politics/2015/04/true-cost-of-gun-violence-in-america/.

131 Id.

132 Everytown for Gun Safety, Latest Gun Violence Research: States With Background Checks Have Fewer Domestic Violence Homicides, Fewer Police Killed by Guns, Everytown fOr Gun SAFETy, January 16, 2015, available at https://everytown.org/press/latest-gun-violence-research-states-with-backgroundchecks-have-fewer-domestic-violence-homicides-fewer-police-killed-by-guns/.

133 Id.

134 Kara Rudolph et al, Association Between Connecticut's Permit-to-Purchase Handgun Law and Homicides 105 American Journal of Public Health 8, 49-54 (2015).

135 Daniel Webster, Cassandra Kercher \& Jon Vernick, Effects of the Repeal of Missouri's Handgun Purchaser Licensing Law on Homicides 91 Journal of Urban Health: Bulletin of the New York Academy of Medicine 3, 293-302 (2014). 
A general outlook would suggest that an efficient approach for a complete assessment of the possible impact of permissive gun laws would be to compare the states with the most permissive policies vis-à-vis those with the strictest ones. A 2016 study found that the 10 states with the weakest gun laws in the U.S. collectively experienced three times more gun violence compared with the average of the ten states with the strongest gun laws. ${ }^{136}$ This comparison between states suggests that more permissive gun laws seem to be linked to higher levels of gun violence. Since states in the U.S. have the right to dictate certain gun laws, this ultimately reminds us how different states have taken different approaches to gun laws, and how these policy decisions have led to differing gun violence outcomes.

\section{Policy Implications and Conclusions}

Would more permissive gun laws have the effect of reducing violence in Mexico? By analyzing experiences with gun laws in the U.S., where guns are more prevalent, this analysis indicates that guns do not have a deterrent effect on violence, and in fact can lead to more gun deaths. Therefore, based on results from the U.S., there is no evidence to support the hypothesis that more firearms would have a deterrent effect in Mexico.

In addition to rejecting the hypothesis that more guns imply less crime, this study also found relevant data and research that raise additional questions and concerns drawn from the U.S. experience. These concerns need to be addressed in Mexico's social context. First, if the U.S., a developed country with relatively strong security institutions, has serious problems related to gun violence, how would similar gun laws affect a country with weaker security institutions, such as Mexico? Ninety percent crimes are not reported to authorities in Mexico, presenting staggering levels of impunity. ${ }^{137}$

For instance, evidence suggests that instead of reducing crime, the implementation of permissive gun laws could potentially keep arming criminal groups. Today, most firearms in Mexico are illegally trafficked from the U.S. ${ }^{138}$ As evidence from the U.S. suggests, permissive gun laws and higher levels of gun ownership are associated with more guns being stolen and diverted to criminal networks. Therefore, should more permissive gun laws be

136 Chelsea Parsons \& Eugenio Weigend, America under fire, CEnTER FOR AmERICAN Progress, October 11, 2016, available at https://cdn.americanprogress.org/wp-content/uploads/2016/10/11100940/AmericaUnderFire-report.pdf.

137 Instituto Nacional de Estadística y Geografía (INEGI), Encuesta Nacional de Victimización y Percepción sobre Seguridad Pública 2017 (2017).

138 Bureau of Alcohol, Tobacco, Firearms and Explosives (ATF), International Firearms Trace Data Mexico 2010-2015 (2016), available at https://wrwreatf.gov/docs/internationalfirearmstracedatamexicocy2010-2015pdf/download. 
adopted in Mexico, it is likely that these regulations would contribute to arming criminal groups.

Another fundamental question that follows from this assessment is how these permissive gun laws would affect Mexican police forces. Evidence from the U.S. suggests that police officers are more vulnerable to gun violence in states with permissive gun laws, whether conducting an arrest, addressing violent disputes or simply stopping a vehicle for speeding. Were there more guns, would these actions place law enforcement officers at higher risk in Mexico? Available evidence suggests that, at the very least, this issue should be considered as a key element in the debate.

Another factor that deserves further debate is whether more permissive gun laws could also escalate other forms of violence. For instance, how will easy access to guns in Mexico affect violence against women? According to Mexico's National Institute for Statistics and Geography (Instituto Nacional de Estadistica y Geografia, INEGI), two out of three women in Mexico already suffer from some kind of violence related to gender. ${ }^{139}$ Specialists report that 44 percent of women in Mexico are victims of violence caused by their intimate partners. ${ }^{140}$ In the U.S., women's risk of being killed at home when there is a gun increase significantly. Would the situation be different (or better) in Mexico? Probably not.

Other risks associated to permissive gun laws also deserve attention. For instance, what would happen with regards to school violence in Mexico? To date, there have been some cases of students bringing knives and other nonfirearm weapons to schools, but these could easily be substituted for firearms. In this regard, Mexico experienced a mass school shooting in Monterrey, Nuevo León, in 2017, and additional cases have occurred in which students have brought guns to educational premises. ${ }^{141}$ Mexico presents higher rates of bullying in schools when compared to other Organization for Economic Co-operation and Development (OECD) countries. ${ }^{142}$ Adding firearms to this already growing concern is likely to result in additional fatal outcomes, such as an increase in suicides.

139 Instituto Nacional de Estadística y Geografía, Resultados de la Encuesta NaCiOnal Sobre la DinÁmica de las Relaciones en los Hogares, available at http://wrerreinegi.org. $m x /$ saladeprensa/boletines/2017/endireh/endireh2017_08.pdf.

140 Id.

141 Paulina Villegas, Mexican Student Fatally Shoots Himself in Classroom After Wounding Four, The New York Times January 18, 2017, available at https://wrere.nytimes.com/2017/01/18/ world/americas/mexico-school-shooting-monterrey.html; Luciano Campos Garza, Suspenden a alumna que llevó pistola a secundaria privada de Monterrey, Proceso, October 24, 2017, at http:// wrerc.proceso.com.mx/508671/suspenden-a-alumna-llevo-pistola-a-secundaria-privada-monterrey.

142 Organization for Economic Cooperation and Development, How much of a probLEM IS BULLYING AT SCHOOL? PISA IN Focus \#74, available at http://werere.oecd-ilibrary.org/docserver/download/728d6464-en.pdf?expires $=1510940200$ Eid $=i d$ Eaccname $=$ guest Echecksum $=1$ C4E0 3315AC63A87BD0318022223B077. 
Esta revista forma parte del acervo de la Biblioteca Jurídica Virtual del Instituto de Investigaciones Jurídicas de la UNAM http://www.juridicas.unam.mx/ https://biblio.juridicas.unam.mx/bjv https://revistas.juridicas.unam.mx/ http://dx.doi.org/10.22201/iij.24485306e.2019.1.13127

If a more permissive gun law is adopted in México, it could also potentially experience an increase in gun confrontations derived from vehicle related accidents. This type of violence has escalated in the U.S. in recent years and could potentially become a problem in Mexico. Policy decision makers must consider that Mexico is a country with high levels of vehicle related accidents, and that fatal encounters with guns during road incidents have already occurred. ${ }^{143}$ Evidence suggests that problems such as road rage incidents can escalate if guns become more available.

We assume decision makers in Mexico have the best intentions when suggesting permissive gun laws. However, if they consider replicating U.S. gun policies, they must also analyze the potential flaws in their diagnosis, as well as the possible negative effects, costs, and consequences of such laws.

Instead of adopting strategies that increase the availability of guns among the population, the discussion should be centered on how to reduce access to illegal firearms for criminal groups. Even policy makers that support permissive gun laws agree that reducing illegal gun trafficking is crucial. The federal government should incorporate a more balanced security strategy that incorporates firearms trafficking as a priority. This is key, since one of the necessary conditions for drug markets to become more violent is the availability of firearms. At the same time, firearms provide criminal groups with the opportunity to diversify from drug markets into other types of criminal activity such as kidnappings and robberies. In fact, crimes such as illegal mining or violent oil theft have risen in recent years, the latter having a dramatic impact in Mexico. ${ }^{144}$ It is debatable as to whether these violent crimes would occur if criminal groups had no access to powerful guns.

It is a fact that Mexico is experiencing a serious challenge in terms of criminal violence, and something must be done to address it. However, instead of adopting permissive gun laws, Mexico should adopt a holistic strategy. Among other strategies, impunity rates must be reduced by devoting substantial political and financial efforts to design a clear strategy to complete the judicial reform in force since 2016. Likewise, security institutions must be strengthened with a specific emphasis on what has worked domestically and internationally, particularly in the fields of social and situational crime prevention. For this to happen, comprehensive police reform that focuses not only on redesigning the institutional framework, but also on increasing sala-

143 Toluca Noticias, Conductor de BMW mata a chofer de autobús por un "cerrón" en San Mateo Atenco, Toluca Noticias, February 7, 2015, at http://werere.tolucanoticias.com/2015/02/conductorde-bmw-mata-chofer-de-autobus.html.

144 Alberto Najar, Minería, el nuevo negocio de los carteles mexicanos, BBC Mundo, May 1, 2017, at http://wrerrebbc.com/mundo/noticias/2014/03/140318_mexico_mineria_nuevo_negocio_carteles_narcotrafico_templarios_zetas_an; Sergio Rincón, El millonario negocio del robo de combustible por el crimen organizado en época de escasez en México, Univision Noticias, December 29, 2016, at http:// wrere.univision.com/noticias/crimen-organizado/el-millonario-negocio-del-robo-de-combustible-por-crimenorganizado-en-epoca-de-escasez. 
ries and working conditions, seems to be an efficient and sustainable way to tackle crime. ${ }^{145}$

From a general perspective, Mexico can learn much about successful policies from the U.S., but permissive gun laws are not one of those successes. Instead, Mexico would do well to follow the example of other countries like Australia, where stricter gun laws may have contributed to reducing gun related crimes. ${ }^{146}$ In the end, the evidence is clear: a safer society is not one where firearms are more available, but one where they are not needed or used at all.

145 Bernardo González-Aréchiga, et al., ¿Cómo transformar las policías? Análisis de opciones y estrategias para reformar el mando policial en MéXico, Tirant lo BLANCH (2017).

146 Simon Chapman, et al, Association Between Gun Law Reforms and Intentional Firearm Deaths in Australia, 1979-2013, 316 JAMA 3, 291-299 (2016). 